Gut, 1963, 4, 339

\title{
An antibody precipitating urease and its possible relation to gastric ulcer ${ }^{1}$
}

\author{
F. S. FREISINGER \\ From the Department of Surgery, Royal Free Hospital Medical School, London
}

EDITORIAL SYNOPSIS An antibody precipitating urease was found in 171 out of 180 human sera. Data obtained on limited material (50 cases) suggest that the anti-urease titre is appreciably higher in the serum of patients suffering from gastric ulcer. This is a pointer towards a possible antigenantibody mechanism in the genesis of chronic gastric ulceration.

Urease was the first enzyme to be produced in crystalline form (Sumner, 1926). It breaks down urea into ammonia and $\mathrm{CO}_{2}$ and occurs in numerous bacteria and in a variety of plants. Among the latter, it is most concentrated in the Soya bean and the Jack bean. Urease also occurs in the animal body. Traces have been found in the pituitary gland, the liver, and the red cells, but it occurs in greater quantities in the superficial layers of the gastric mucosa and in the gastric mucus of man and mammals, particularly carnivores (Fitzgerald, 1946; Fitzgerald and Murphy, 1950; Strehler, 1954 and 1955). Kornberg, Davies, and Wood (1954) investigated the breakdown of urea in the gastric mucosa of the cat by means of urea labelled with ${ }^{14} \mathrm{C}$ and established that there is an increase in the breakdown of tracer urea within the gastric mucosa following stimulation of the gastric glands with histamine. The process increases after infusion of urea into the stomach and cannot be detected when the stomach glands are at rest. Many authors have assumed that this production of ammonia, which occurs simultaneously with acid secretion, plays a physiological role in the protection of mucosa against peptic digestion by keeping the reaction of the mucosa in the alkaline range (Fitzgerald, 1946; Fitzgerald and Murphy, 1950; Freisinger, 1956 and 1961; Luck and Seth, 1925; Strehler, 1954).

A histochemical method for the demonstration of gastric urease in microscopic sections has been developed, and this will be the subject of a separate communication. Figure 1 shows the distribution of urease in the gastric mucosa of a dog. In previous studies (Freisinger, 1956 and 1961) I measured the

\footnotetext{
${ }^{1}$ This is a preliminary communication based on work begun at the Institute of Clinical Research, Middlesex Hospital Medical School, where it was supported by a Leverhulme research scholarship and formed the basis of a Ph.D. thesis (London, 1961).
}

urease activity and the urea content of mucosal homogenates from ulcer patients, cancer patients, and normal subjects (operative and biopsy samples) by Conway's micro-diffusion method (Conway and Byrne, 1933), using Jack bean urease for the enzymatic breakdown of urea. The urea content of the stomach homogenates was furthermore estimated colorimetrically by the xanthydrol method (Lee and Widdowson, 1937). In the course of these estimations a curious fact emerged: in normal stomachs enzymatic and colorimetric estimations of urea with xanthydrol usually led to identical results. In homogenates of mucosa from patients suffering from gastric ulcer, however, the values obtained with urease were always lower than those obtained by the colorimetric method. An inhibitory factor appeared to be present in ulcer patients which suppressed Jack bean urease activity in vitro.

As a working hypothesis it was assumed that this factor might be an antibody to urease similar to the 'anti-urease' produced in rabbits by Kirk and Sumner (1934) by immunizing the animals with crystalline urease. Injections of urease give rise to toxic levels of ammonia by the breakdown of blood urea but this precipitating antibody was able to protect the rabbits against no fewer than 1,000 lethal doses of urease.

The present study was undertaken to verify the existence of an antibody to urease in human subjects and to establish its possible relation to gastric ulcer.

\section{METHODS}

Pure crystalline urease was extracted from Jack beans by the method of Sumner and Myrbäck (1951) and twice recrystallized using Dounce's method (1941). The crystals had an activity of 133,000 Sumner units per gram, the Sumner unit being defined as the amount of 


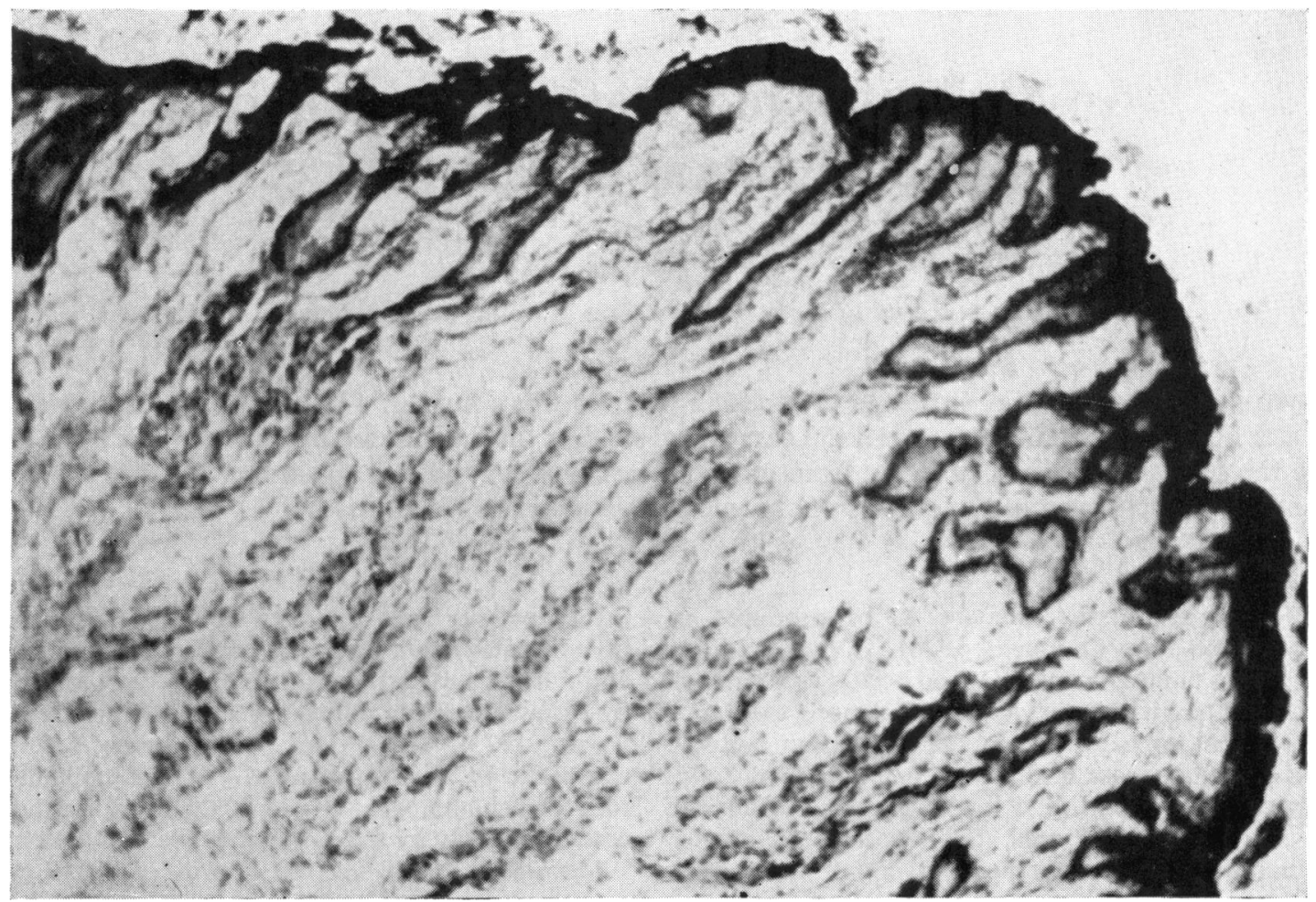

FIG. 1. Histochemical demonstration of urease in the gastric mucosa of a dog. The black zone indicates urease activity; the latter is mainly confined to the surface of the mucosa and the parietal cells.

urease which will produce $1 \mathrm{mg}$. ammonia-nitrogen from a $3 \%$ urea solution at a $\mathrm{pH}$ of 7.0 in five min. at $20^{\circ} \mathrm{C}$.

To demonstrate the antibody the method of precipitation in gel in a modification of the method of Oakley and Fulthorpe (1953) was used: $0 \cdot 1 \mathrm{ml}$. of crystalline urease solution buffered at a $\mathrm{pH}$ of 6.94 in a strength of 90 Sumner units per $\mathrm{ml}$. was mixed with $0.1 \mathrm{ml}$. liquid $1 \%$ clarified agar at $56^{\circ} \mathrm{C}$. and filled into the bottom of Widal tubes. After the agar had solidified, it was covered by 0.2 ml. of $0.33 \%$ clarified agar and the tubes were kept overnight. Next day, increasing doubling dilutions of serum were added on top of the second agar layer (portions of $0.15 \mathrm{ml}$. up to a dilution of $1: 1,024)$ and the tubes were sealed. This test was carried out with 180 sera, including 50 sera of patients suffering from gastric ulcer.

In a limited number of cases ( 36 sera) attempts were also made to estimate the amount of precipitate by quantitative immunochemical methods. For this purpose, increasing concentrations of urease solution were incubated with $1 \mathrm{ml}$. portions of human sera for two hours at $37^{\circ} \mathrm{C}$. and for 48 hours at $4^{\circ} \mathrm{C}$. at a $p \mathrm{H}$ of $7 \cdot 0$. Small precipitates were obtained which could be spun down in a refrigerated centrifuge at $2^{\circ} \mathrm{C}$., washed twice in ice-cold saline, and then dissolved in $0.1 \mathrm{~N} \mathrm{NaOH}$ and measured spectrophotometrically in ultraviolet light (wavelength 2,800 $\AA$ ). Before incubation the urease activity of the serumurease mixture was measured and compared with the activity of the supernatant after the precipitate had been spun down.

In addition, the precipitin reaction was repeated by immunoelectrophoresis on cellulose acetate strips as described by Consden and Kohn (1959) to establish the location of the antibody in the serum protein fractions.

\section{RESULTS}

PRECIPITATION IN GEL In $93.1 \%$ of cases a precipitin ring developed within 48 to 96 hours in the first few tubes high up in the central column of clear agar (Fig. 2); the 'anti-urease-titre' of the serum can be defined as the highest dilution of serum still giving a visible precipitin ring. In most cases the ring is visible up to a dilution of 32 or 64 (see Table). The average titre in 130 sera of persons with no history of ulcer was $48 \cdot 5$. In sera of patients suffering from clinically confirmed gastric ulcer (50 cases) the ring was usually visible up to a titre of 256 , sometimes up to 512 , and was only in two cases lower than 128 , one of which concerned a healed ulcer and the other a large irregular ulcer (radiologically thought to be benign) in a patient aged 70 years. Five out of eight 


\section{Serum}

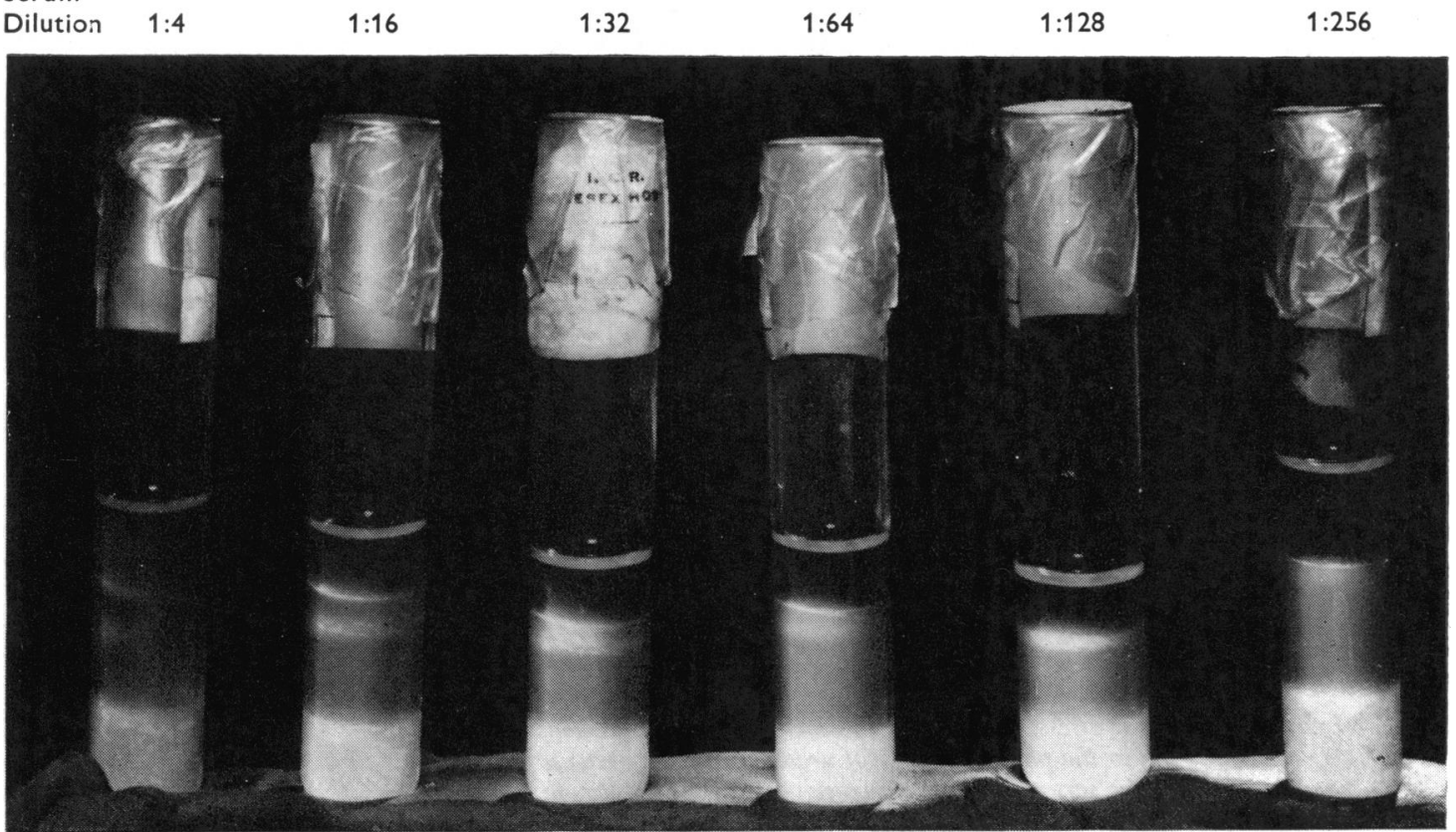

FIG. 2. The modified Oakley-Fulthorpe precipitin test in gel. Top layer: Serum from a gastric ulcer patient (increasing dilutions). Middle layer: Neutral semiliquid agar. Bottom layer: Antigen (crystalline urease solution) mixed with $1 \%$ agar. Note maximum density (equivalence zone) in third tube and regular relation between distance of ring from the top and serum dilution.

patients in whom the titre reached 512 had bleeding ulcers. The average titre of 50 ulcer patients was 240 .

Sera of patients suffering from duodenal ulcer were deliberately excluded from the present series. It may, however, be noted that some of them behaved like normal sera, others gave results similar to gastric ulcer sera; as a result the mean values for duodenal ulcer occupy an intermediate position between the values for gastric ulcer and the normal level. About $11 \%$ of patients with no known history of ulcer also reached a titre of 128 which seems to represent in the described semiquantitative method a 'borderline titre' where a certain overlapping occurs. Figure 2 shows the results of a gel test carried out with the serum of a gastric ulcer patient; the ring increases in density with increasing serum dilutions up to $1: 32$ (third tube) and then decreases again (zone of equivalence).

RESULTS OF QUANTITATIVE TESTS Five out of 36 sera investigated gave no appreciable precipitate. Nineteen sera which had given a low titre in the gel test produced a small precipitate, the amount of which was estimated against a reference curve of spectrophotometric absorption drawn with a known $\gamma$

TABLE

ANTI-UREASE TITRES IN PATIENTS SUFFERING FROM GASTRIC ULCER AND IN PERSONS WITH NO HISTORY OF GASTRIC ULCER ${ }^{1}$

Serum Dilution $1: 4$ or less $1: 16$ $1: 32$ $1: 64$ $1: 128$ $1: 256$ $1 \cdot 512$ Total

No. of gastric ulcer patients

\begin{tabular}{|c|c|c|c|c|c|c|c|}
\hline 一 & - & $1(2 \%)^{2}$ & $1(2 \%)^{3}$ & $18(36 \%)$ & $22(44 \%)$ & $8(16 \%)^{4}$ & $50(100 \%)$ \\
\hline$(6.92 \%)$ & $37(28.46 \%)$ & $20(15 \cdot 38 \%)$ & $49(37.7 \%)$ & $15(11.53 \%)$ & - & - & $130(100 \%)$ \\
\hline
\end{tabular}

No. of persons with no history of ulcer $9(6.92 \%) \quad 37(28.46 \%) \quad 20(15.38 \%) \quad 49(37.7 \%) \quad 15(11.53 \%)-$

'Large 'titre' indicates the reciprocal value of the highest seru

'Described clinically as 'healed ulcer'.

'Five out of the above eight cases concerned bleeding ulcers. 


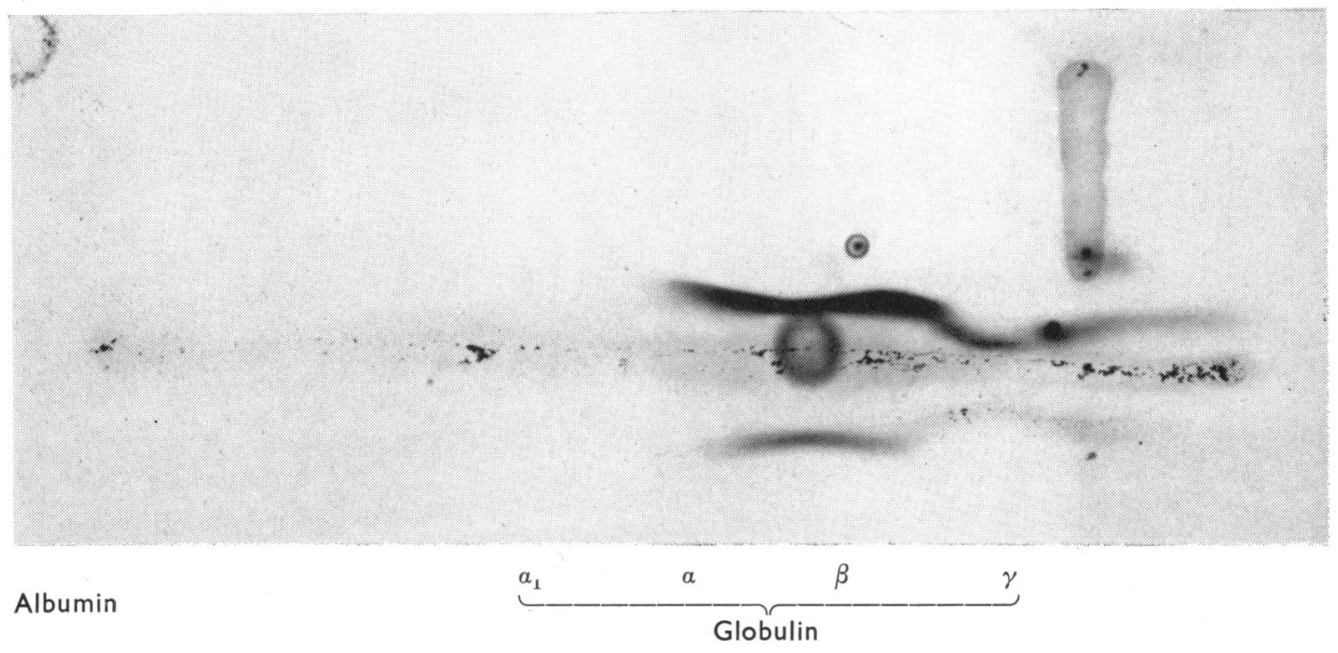

Gastric ulcer serum

Antigen

Normal serum

FIG. 3. Immuno-electrophoretic strip showing the location of the antibody. In the central line the antigen (crystalline urease) was applied; (due to the poor solubility of urease traces of antigen protein show in the central strip). The upper side of the strip contains the serum of a gastric ulcer patient, the lower side a normal serum both distributed by electrophoresis. A zone of precipitated insoluble protein formed, corresponding to the $\beta$ globulin fraction and, to a lesser degree, in the $\gamma$ globulin fraction. The zone is visibly stronger in the upper strip (gastric ulcer).

globulin solution. It increased with rising concentration of antigen, reached a maximum, and decreased again, giving typical precipitin curves as described in the quantitative precipitin estimation by Heidelberger and Kendall (1935a and b). Those sera which had shown higher titres in the gel test (12 sera) gave on the average three or four times larger precipitates than the sera with 'low' titres. Attempts to measure the actual amount of precipitated protein by chemical methods, and investigations regarding other immunological properties of the 'anti-urease', e.g., antigen-antibody ratio, complement-fixation, are at present in progress.

LOSS OF UREASE FROM THE SUPERNATANT The urease content of the supernatant fluid after removal of the precipitate as estimated by Conway's method was found to decrease parallel to the amount of precipitate assessed spectrophotometrically.

LOCATION OF THE ANTIBODY IN THE SERUM PROTEIN FRACTIONS Immuno-electrophoresis on cellulose acetate strips gave well-marked precipitin lines extending over most of the globulin area with a clear maximum in the $\beta$ globulin fraction. The relative density of the lines in cases with high titres and low titres respectively corresponded to the findings in the gel tests. Figure 3 shows an immuno-electrophoretic strip with the anti en in the middle line, the serum of an ulcer patient at the top, and a normal serum at the bottom: the precipitin line produced by the serum of the ulcer patient is visibly more intense than the line produced in the same globulin fraction by the normal serum.

\section{DISCUSSION}

The almost ubiquitous presence of anti-urease in human sera-at least in low titres-is not surprising, although the fact has not been commented upon. Urease is a substance of particularly high antigenicity (Strehler, 1955) and contact with urease-containing bacteria such as staphylococcus, Mycobacterium tuberculosis, Proteus vulgaris, and many others, might well give rise to traces of anti-urease. However, the higher anti-urease titres found in a large proportion of ulcer cases are of considerable interest. Kornberg et al. (1954) produced evidence for the bacterial origin of gastric urease, but in a more recent paper Conway, Fitzgerald, McGeeney, and Geoghegan (1959) were able to refute this view.

The likely physiological role of urease is that of protection against acid digestion. Strehler (1954) tried feeding urease-active Soya bean powder to patients and found a decrease in the gastric acidity. Fitzgerald (1946) found increased (compensatory?) urease activity in the mucosa of patients with duodenal ulcer. 
The existence of an antibody to urease in human subjects brings a new factor into consideration. It seems desirable to screen a larger number of sera to establish a statistical relation between gastric ulcer and high anti-urease titres, as the present data gained from 50 ulcer cases can be regarded as suggestive but not as conclusive. The next step would be an attempt to establish a causative relation between high antiurease titres and gastric ulcer, particularly in regard to the possible pathogenetic role played by local antigen-antibody contact at the site of lesions of the mucosa in the development of a chronic ulcer from an acute erosion.

I wish to thank Dr. G. D. Hadley and Professor A. Kekwick (Middlesex Hospital) for constant help and advice, as well as Dr. D. Doniach and Dr. Roitt for their advice in matters of immunological techniques. I am grateful to Mr. Daintree Johnson, the Department of Surgery, and the Board of Governors of the Royal Free Hospital for the granting of facilities which enable me to continue the work begun with the present study.

\section{REFERENCES}

Consden, R., and Kohn, J. (1959). Cellulose acetate as a medium for immuno-diffusion. Nature (Lond.), 183, 1512-1513.

Conway, E. J., and Byrne, A. (1933). An absorption apparatus for the micro-determination of certain volatile substances. I. The micro-determination of ammonia. Biochem. J., 27, 419-429.

_-, Fitzgerald, O., McGeeney, K., and Geoghegan, F. (1959). The location and origin of gastric urease. Gastroenterology, 37, 449-456.

Dounce, A. L. (1941). An improved method for recrystallizing urease. J. biol. Chem., 140, 307-308.
Fitzgerald, O. (1946). Urease in the gastric mucosa and its increase after a meat diet, soya bean flour diet or urogastrone injections. Nature (Lond.), 158, 305.

- , and Murphy, P. (1950). Studies on the physiological chemistry and clinical significance of urease and urea with special reference to the stomach. Irish J. med. Sci., 97-159.

Freisinger, F. S. (1956), Pathogenesis of gastric ulcer on the basis of histological and experimental investigations. Thesis. (In Hungarian).

- (1961). An antibody to urease and its possible relation to gastric ulcer. Ph.D. Thesis, London.

- (1963). A histochemical method for the demonstration of gastric urease. To be published.

Heidelberger, M., and Kendall, F. E. (1935a). The precipitin reaction between ty pe III pneumococcus polysaccharide and homologous antibody. III. A quantitative study and a theory of the reaction mechanism. J. exp. Med., 61, 563-591.

,$--(1935 \mathrm{~b})$. A quantitative theory of the precipitin reaction. III. The reaction between crystalline egg albumin and its homologous antibody. Ibid., 62, 697-720.

Kirk, J. S. , and Sumner, J. B. , (1934). The reaction between crystalline urease. J. Immunol., 26, 495-504.

Korff, R. W., Ferguson, D. J., and Glick, D. (1951). Role of urease in the gastric mucosa. III. Plasma urea as source of ammonium ion in gastric juice of histamine-stimulated dog. Amer. J. Physiol., 165, 695-700.

Kornberg, H. L., Davies, R. E., and Wood, D. R. (1954). The activity and function of gastric urease in the cat. Biochem. J., 56, 363-372.

Lee, M. H., and Widdowson, E. M. (1937). The micro-determination of urea in blood and other fluids. Ibid., 31, 2035-2045.

Luck, J. M., and Seth, T. N. (1925). The physiology of gastric urease. Ibid., 19, 357-365.

Oakley, C. L., and Fulthorpe, A. J. (1953). Antigenic analysis by diffusion. J. Path. Bact., 65, 49-60.

Strehler, E. (1954). Zur Physiologie der Salzsaüresekretion des Magens. (3) Die wirkung-peroral varabreichter ureasehaltiger Soyaund Jackbohnenextrakte auf die Magenaciditätsverhältnisse. Helv. med. Acta, 21, 128-140.

- (1955). Zur physiologie der Salzsaüresekretion des Magens. (4) Ubersicht über die Urease und die Bedeutung ihres Vorkommens im magen. Ibid., 22, 83-97.

Sumner, J. B. (1926). Isolation and crystalization of the enzyme urease. J. biol. Chem., 69, 435-441.

—, and Myrbäck, K. (1951). The Enzymes, vol. I, pt. 2, ch. 24 Academic Press, New York. 